Ekuitas:Jurnal Pendidikan Ekonomi

Volume 9, Number 1, Tahun 2021, pp. 199-205

P-ISSN : 2354-6107 E-ISSN : 2549-2292

DOI : $10.23887 /$ ekuitas.v9i1.34373

Open Access: https://ejournal.undiksha.ac.id/index.php/EKU

\title{
Persepsi dan Pemahaman Pelaku Usaha Terhadap Pentingnya Laporan Keuangan pada UMKM
}

\section{${\text { Mohammad David Santiago }{ }^{*} \text {, Sri Dwi Estiningrum² }}^{2}$}

\author{
1,2IAIN Tulungagung, Tulungagung-Indonesia
}

\section{A R T I C L E I N F O}

Article history:

Received May, 92021

Received in revised form

June, 32021

Accepted June, 82021

Available online June, 28

2021

\section{Kata Kunci:}

Laporan keuangan,

persepsi, pemahaman,

pelaku UMKM.

Keywords:

Financial statements, perception, understanding UMKM actors.

\begin{abstract}
A B S T R A K
Penelitian ini memiliki tujuan untuk mengetahui persepsi dan pemahaman pelaku Usaha Mikro Kecil Menengah (UMKM) terhadap pentingnya laporan keuangan. Dalam penelitian ini merupakan jenis penelitian deskriptif kuantitatif. Penelitian ini menggunakan data primer yang diperoleh dari hasil kuesioner yang disebar kepada 70 pelaku UMKM di Kabupaten Tulungagung yang tersebar di 19 Kecamatan. Hasil penelitian menunjukkan bahwa persepsi pelaku UMKM di Kabupaten Tulungagung sudah menunjukan persepsi yang baik terbukti dengan hasil penelitian bahwa rata-rata repsonden sudah mengetahui pentingnya laporan keuangan dalam sebuah usaha diantaranya untuk mengetahui perkembangan usaha, mendukung kepentingan usaha seperti kepentingan pajak dan kepentingan pengajuan kredit ke Bank sebagai tambahan modal. Persepsi yang baik ini dipengaruhi oleh pengalaman atau lamanya menjalankan usaha dan juga latar belakang pendidikan. Namun pemahaman pelaku UMKM di Tulungagung masih perlu di tingkatkan karena masih ada pelaku usaha di Tulungagung yang tidak mengetahui bagaimana menyusun laporan keuangan sesuai standar yang berlaku meskipun mereka mengetahui pentingnya laporan keuangan hal tersebut disebabkan oleh faktor kompetensi yang dimiliki oleh pelaku usaha dan dipengaruhi oleh latar belakang pendidikan. Ada beberapa pelaku usaha yang tidak mengetahui konsep penjurnalan transaksi padahal hal ini menjadi dasar dalam menyusun laporan keuangan.
\end{abstract}

\section{A B S T R A C T}

This study aims to see the perceptions and understanding of entrepreneurs of Micro, Small and Medium Enterprises (MSMEs) on the importance of financial reports." This research is a type of quantitative descriptive research. This study uses primary data obtained from the results of a questionnaire distributed to 70 MSME actors in the famous Tulungagung Regency in 19 Districts. The results showed that MSME actors in Tulungagung Regency have shown good perceptions as evidenced by the results of the research that on average reports are ready to prepare financial reports in a business, including to see business development, support business interests such as tax interests and the interest of applying for credit to the bank. as additional capital. Good perceptions of these students by experience or experience running a business and educational background. However, the understanding of MSME actors in Tulungagung still needs to be improved because there are still business actors in Tulungagung who do not see how to prepare financial reports according to standards that support them to help financial reports, this is due to the factor of human resource competence built by educational background. There are some business actors who do not know the concept of journalizing transactions, even though this is the basis for preparing financial reports.

\footnotetext{
* Corresponding author.

E-mail : mohammaddavid09@gmail.com (Mohammad David Santiago)
} 


\section{Pendahuluan}

Secara keseluruhan jumlah pelaku UMKM di Indonesia terus mengalami kemajuan cukup pesat, pernyataan ini didukung data dari Badan Pusat Statistik (BPS) tahun 2017 ada 56,6 juta dan pada tahun ini meningkat menjadi 59,2 juta. Hal ini dapat menyerap tenaga kerja secara nasional sebesar $97 \%$ dan bahkan mampu memberikan kontribusi PDB sekitar 57\% (Akuntansi et al., 2020). Demikian juga untuk wilayah Provinsi Jawa Timur, khususnya Kabupaten Tulungagung. Tulungagung dipandang sebagai daerah yang sangat strategis dan produktif, selain lahannya yang cukup luas, Kabupaten Tulungagung juga mempunyai lahan yang sangat subur untuk tanaman yang bisa diolah dan dijadikan bahan yang kreatif dan inovatif. Laju pertumbuhan UMKM di Kabupaten Tulungagung meningkat cukup pesat selama 5 tahun terakhir.

Jumlah UMKM di Tulungagung berdasarkan data dari Dinas Koperasi UMKM Kabupaten Tulungagung dari tahun 2014 sampai dengan 2018 mengalami peningkatan. Terbukti bahwa pada tahun 2014 total UMKM berjumlah 44.633 dan pada tahun 2018 meningkat menjadi 55.649. Hal ini menunjukkan bahwa perkembangan jumlah UMKM di Kabupaten Tulungagung berkembang sangat pesat hanya dilihat dari 5 tahun terakhir. Ketika jumlah pelaku usaha meningkat secara otomatis persaingan usaha juga tidak bisa dihindari. Pada dasarnya persaingan tersebut disebabkan karena semua pelaku usaha tentunya ingin mencapai tujuan usahanya yaitu profit secara efisien dan efektif.

Saat ini UMKM merupakan sektor usaha yang mempunyai peranan penting. Tetapi hal tersebut tidak terlepas dari sebuah permasalahan. Masalah yang secara umum dihadapi oleh para pelaku UMKM adalah terkait permodalan. Para pelaku usaha yang minim akan pengetahuan sulit untuk mengajukan pembiayaan dilembaga keuangan sebagai tambahan modal. Permasalahan ini disebabkan oleh ketidakmampuan seorang pelaku usaha dalam membuat laporan keuangan yang disebabkan oleh kurangnya pengetahuan tentang akuntansi. Dalam hal ini kemampuan pelaku usaha sangat diperlukan dalam menghadapi kemajuan demi menjaga kestabilan usaha dalam persaingan.

Seperti yang telah dipaparkan di atas bahwa permasalahan yang dihadapi oleh UMKM salah satunya adalah kurangnya kemampuan manajerial serta kemampuan operasional oleh pelakunya (Suci et al., 2017), tingkat pendidikan yang kurang mendukung dan juga belum pernah mengikuti pelatihan akuntansi (Kurniawati et al., 2012). Masalah yang dialami oleh pelaku UMKM ketika mau membuat atau menyusun sebuah laporan keuangan adalah kurangnya pemahaman pelaku usaha tentang standar penyusunan laporan keuangan yang berlaku dan juga belum melakukan pemisahan aset yaitu antara aset pribadi dan aset perusahaan, dan hal ini akan menyulitkan ketika menyusun laporan keuangan (Setiyawati \& Hermawan, 2018). Hasil penelitian (Mutiah, 2019) menyatakan bahwa yang menjadi kendala utama bagi pelaku usaha untuk menyusun laporan keuangan adalah terbatasnya pemahaman pelaku usaha tentang penyusunan laporan akuntansi yang disebabkan oleh kurangnya pengetahuan standar akuntansi yang berlaku.

Persepsi pelaku UMKM mengenai penggunaan sistem informasi akuntansi pada usahanya juga dipengaruhi oleh pengalaman yang dimiliki pelaku usaha tersebut. Pengalaman berapa lamanya pelaku usaha menjalankan usahanya dengan menghendaki kebutuhan terkait informasi manajemen dan akuntansi yang diperlukan perusahaan. Ketika sebuah perusahaan sudah lama dijalankan dan berkembang maka kebutuhan informasi akuntansi semakin meningkat karena kerumitan yang timbul dalam usahanya akan semakin tinggi. Persepsi pelaku usaha atas pentingnya informasi akuntansi juga dipengaruhi oleh jenjang pendidikan yang dimiliki pengelola usaha. Pelaku usaha yang mempunyai tingkat pendidikan yang rendah cenderung mengarah pada kualitas penyusunan laporan keuangan yang rendah jika begitupun sebaliknya. Hal ini menunjukkan bahwa pemahaman pelaku usaha mengenai pentingnya informasi akuntansi sangat dipengaruhi oleh tingkat pendidikan terakhir (Ariono \& Sugiyanto, 2018).

Penerapan informasi akuntansi keuangan pada UMKM sangat bermanfaat untuk mengetahui perkembangan usaha dan keuangannya. Seperti dalam hal permodalan, keuntungan maupun kerugian yang didapatkan oleh perusahaan pada suatu periode yang ditentukan. Oleh karena itu, dalam pengelolaan usaha kecil maupun menengah juga perlu membutuhkan seorang yang memiliki kemampuan dan keahlian di bidang usaha, organisasi, manajemen dan akuntansi (Ariono \& Sugiyanto, 2018). Informasi akuntansi yang ada pada laporan keuangan berguna bagi perusahaan untuk mengetahui modal yang dimiliki, keadaan keuangan, untuk mengambil keputusan dalam setiap permasalahan serta dapat juga digunakan untuk menarik minat investor. Pengetahuan akuntansi yang dimiliki seorang pelaku usaha dapat dilihat melalui pengalaman dalam mengikuti pelatihan program dan seminar tentang akuntansi. Semakin tinggi tingkat pemahaman tentang akuntansi oleh pelaku usaha, maka semakin baik penyusunan informasi akuntansi pada usahanya. Selain itu apabila pelaku memiliki kemampuan akuntansi maka akan mempengaruhi dalam adaptasi bisnis dari uasaha yang dijalankan (Rekarti \& Doktoralina, 2017).

Laporan keuangan menurut (Yolanda, 2014 ) yaitu suatu informasi akuntansi yang memiliki peran sangat penting dalam memperoleh sebuah keberhasilan pada suatu usahanya. Sehingga laporan keuangan 
dapat dijadikan pedoman yang handal untuk pengambilan keputusan ekonomi meliputi pengembangan pasar, menetapkan harga pasaran suatu produk. Permasalahannya masih banyak pelaku usaha yang belum menerapkan pencatatan dan membuat laporan keuangan pada usahanya. Hal ini dapat menyebabkan sulitnya para pelaku usaha khususnya UMKM untuk mendapat tambahan dana permodalan dari perbankan. Penelitian oleh (Yanto et al., 2017) menyatakan bahwa kemampuan UMKM dalam mengakses lembaga keuangan dipengaruhi oleh laporan keuangan yang dihasikan.

Pada saat ini ada pelaku UMKM yang menganggap bahwa dalam proses pembuatan dan pengerjaan laporan keuangan hanya merepotkan saja, menyita banyak waktu, menambah kerumitan pengerjaan dan biaya. Beberapa pelaku usaha sudah ada yang membuat laporan keuangan dalam bentuk sederhana berdasarkan pemahamannya saja. Kasus ini sama dengan kasus yang di ungkap dalam penelitian yang dilakukan oleh (Purwati et al., 2014). Sebenarnya jika pelaku usaha dapat menyusun informasi akuntansi pada sebuah pencatatan laporan keuangannya, maka dapat berguna untuk meningkatkan daya saing, untuk menyusun strategi usahanya dan sebagai dasar pengambilan keputusan atas perencanaan usaha di masa yang akan datang. Diharapkan pelaku UMKM harus memiliki daya saing dan mampu beradaptasi dengan berbagai kemajuan zaman dan meningkatkan kinerja dalam hal manajemen, keuangan, dan profesionalitas dalam bekerja (Mulyani, 2014). Maka dalam hal ini diperlukan semacam program pelatihan atau pendampingan bagi para pelaku UMKM dalam hal mengelola keuangan dengan sistem akuntansi (Kusuma \& Lutfiany, 2019).

Dapat disimpulkan bahwa pemahaman akuntansi UMKM di Tulungagung masih rendah. Hal tersebut dipengaruhi beberapa faktor dari pelaku usahanya sendiri yang meliputi latar belakang pendidikan, pengalaman, pengetahuan dan pemahaman, serta lamanya menjalankan usahanya. Maka penelitian ini bertujuan untuk menganalisis persepsi serta pemahaman pelaku UMKM di Tulungagung terhadap pentingnya sebuah laporan keuangan atas usaha yang dijalankannya.

\section{Metode}

Penelitian ini termasuk ke dalam jenis penelitian deskriptif. Pendekatan yang dipakai oleh peneliti adalah pendekatan kuantitatif. Ada dua variabel dalam penelitian ini yaitu variabel bebas (persepsi dan pemahaman) dan variabel terikat (pentingnya laporan keuangan). Tujuan dari penelitian ini adalah untuk menganalisis persepsi dan pemahaman pelaku UMKM di Tulungagung atas pentingnya laporan keuangan. Populasi dalam penelitian ini adalah UMKM yang melakukan Izin Usaha Mikro Kecil (IUMK) di Dinas Koperasi dan UMKM Kabupaten Tulungagung Tahun 2019. Perhitungan sampel dengan rumus slovin, sebagai berikut:

$$
\mathrm{n}=\frac{\mathrm{N}}{1+\left(\mathrm{Nx} \mathrm{e}^{2}\right)}
$$

\section{Keterangan:}

$\begin{array}{ll}\mathrm{n} & : \text { Jumlah sampel } \\ \mathrm{N} & : \text { Jumlah populasi } \\ \mathrm{e} & : \text { Tingkat kesalahan }\end{array}$

Tabel 1. Jumlah Populasi Berdasarkan Kecamatan

\begin{tabular}{lclc}
\hline Kecamatan & $\begin{array}{c}\text { Jumlah } \\
\text { Responden }\end{array}$ & \multicolumn{1}{c}{ Kecamatan } & $\begin{array}{c}\text { Jumlah } \\
\text { Responden }\end{array}$ \\
\hline Tulungagung & 30 & Besuki & 22 \\
Kedungwaru & 27 & Campurdarat & 15 \\
Kauman & 5 & Tanggunggunung & 7 \\
Pagerwojo & 4 & Kalidawir & 11 \\
Ngantru & 17 & Rejotangan & 11 \\
Sendang & 8 & Ngunut & 15 \\
Gondang & 6 & Sumbergempol & 12 \\
Bandung & 7 & Pucanglaban & 1 \\
Pakel & 7 & Boyolangu & 22 \\
\hline
\end{tabular}

(Sumber: Dinas Koperasi dan UMKM Tulungagung) 
Populasi sebanyak 232 UMKM yang melakukan IUMK pada tahun 2019, lalu peneliti menghitung sampel penelitian dengan rumus slovin dengan tingkat kesalahan sebesar $10 \%(0,1)$. Maka sampel penelitian dapat dihitung seperti di bawah ini

$$
\begin{aligned}
& \mathrm{n}=\frac{\mathrm{N}}{1+\left(\mathrm{N} \mathrm{x} \mathrm{e}^{2}\right)} \\
& \mathrm{n}=\frac{232}{1+\left(232 \times 0,1^{2}\right)} \\
& \mathrm{n}=70
\end{aligned}
$$

Setelah dilakukan perhitungan didapat sampel sebanyak 70 UMKM yang tersebar di 19 Kecamatan di Kabupaten Tulungagung. Penyebaran kuesioner dilakukan dengan cara proporsional sehingga setiap pelaku Usaha di setiap Kecamatan terwakili berdasarkan proporsinya.

Tabel 2. Jumlah Sampel Berdasarkan Kecamatan

\begin{tabular}{lclc}
\hline \multicolumn{1}{c}{ Kecamatan } & Jumlah Responden & \multicolumn{1}{c}{ Kecamatan } & Jumlah Responden \\
\hline Tulungagung & 9 & Besuki & 7 \\
Kedungwaru & 8 & Campurdarat & 5 \\
Kauman & 2 & Tanggunggunung & 2 \\
Pagerwojo & 1 & Kalidawir & 3 \\
Ngantru & 5 & Rejotangan & 3 \\
Sendang & 2 & Ngunut & 4 \\
Gondang & 2 & Sumbergempol & 4 \\
Bandung & 2 & Pucanglaban & - \\
Pakel & 2 & Boyolangu & 7 \\
\hline
\end{tabular}

(Sumber: Data diolah, 2021)

Pengumpulan data menggunakan 3 teknik yaitu observasi, kuesioner dan studi dokumentasi. Data primer diperoleh dari kuesioner. Sedangkan data sekunder diperoleh dari Dinas Koperasi dan UMKM Kabupaten Tulungagung. Teknis analisis menggunakan analisis statistik deskriptif dengan tujuan untuk mendeskripsikan persepsi dan pemahaman pelaku UMKM atas pentingnya laporan keuangan. Analisis data menggunakan aplikasi SPSS versi 26.

\section{Hasil dan Pembahasan}

\section{Persepsi Pelaku Usaha Mikro Kecil Menengah (UMKM) terhadap Pentingnya Laporan Keuangan}

Berdasarkan hasil analisis deskriptif dapat disimpulkan secara keseluruhan persepsi pelaku UMKM di Kabupaten Tulungagung atas pentingnya laporan menunjukan persepsi yang baik. Terbukti bahwa ratarata pelaku UMKM di Tulungagung telah menyadari bahwa dengan laporan keuangan pelaku usaha dapat mengetahui perkembangan usahanya termasuk di dalamnya untuk menilai kesehatan usaha, mendukung kepentingan usaha, sebagai evaluasi juga membantu menyajikan informasi akuntansi yang digunakan sebagai dasar pengambilan keputusan usaha di masa mendatang. Pelaku UMKM di Kabupaten Tulungagung juga memiliki persepsi bahwa dengan laporan keuangan dapat memudahkan pengelolaan usaha dan yang terpenting dengan laporan keuangan pelaku usaha akan dengan mudah dalam pengajuan kredit atau ke Bank sebagai tambahan modal.

Persepsi pelaku UMKM di Kabupaten Tulungagung dipengaruhi oleh beberapa faktor diantaranya ada faktor jenis kelamin, pengalaman, latar belakang pendidikan dan lamanya menjalankan usahanya. Terbukti dari hasil penelitian menunjukan bahwa responden didominasi oleh perempuan. Mayoritas responden dalam penelitian adalah mereka yang memiliki latar belakang pendidikan setara SMA. Yang telah menjalankan usaha rata-rata $>5$ tahun tentunya dalam hal ini sudah cukup banyak memiliki pengalaman dalam menjalankan dan mengelola usaha. 
Beberapa faktor di atas apabila dikaitkan dengan persepsi tentang pentingnya laporan usaha bagi UMKM tentunya sangat berpengaruh. Jadi semakin tinggi pendidikan seseorang maka persepsinya semakin baik karena dibekali dengan ilmu pengatahuan. Pernyataan tersebut sejalan dengan hasil penelitian yang dilakukan oleh (Solikah et al., 2017) dan (Kusuma \& Lutfiany, 2019) yang menyatakan bahwa tingkat pendidikan mempengaruhi persepsi pelaku usaha dalam menyusun laporan keuangan. Lama usaha juga turut mempengaruhi persepsi seorang pelaku usaha untuk menyusun laporan keuangan.

Hasil penelitian ini juga medukung hasil penelitian yang dilakukan oleh (Ariono \& Sugiyanto, 2018) yang menyatakan bahwa persepsi pelaku usaha mengenai penggunaan sistem informasi akuntansi di dalam usahanya juga dipengaruhi oleh pengalaman yang dimiliki pelaku usaha tersebut. Pengalaman berapa lamanya pelaku usaha menjalankan usahanya dengan menghendaki kebutuhan informasi akuntansi yang sangat diperlukan perusahaan, semakin lama perusahaan dijalankan dan berkembang maka kebutuhan informasi akuntansi semakin meningkat karena kerumitan yang timbul di dalam usahanya akan semakin tinggi.

Persepsi pelaku usaha atas pentingnya informasi akuntansi juga dipengaruhi oleh jenjang pendidikan yang dimiliki pengelola usaha. Seperti halnya kemampuan dan keahlian yang dimiliki oleh pemilik usaha sangat mempengaruhi tingkat kualitas laporan keuangan yang digunakan. Pelaku usaha yang mempunyai tingkat pendidikan yang rendah cenderung mengarah pada kualitas penyusunan laporan keuangan yang rendah jika dibandingkan dengan pelaku usaha yang memiliki tingkat pendidikan yang tinggi. Hal ini menunjukkan bahwa pemahaman pelaku usaha mengenai pentingnya informasi akuntansi sangat dipengaruhi oleh tingkat pendidikan terakhir.

\section{Pemahaman Pelaku Usaha Mikro Kecil Menengah (UMKM) terhadap Pentingnya Laporan Keuangan}

Berdasarkan analisis deskriptif tentang pemahaman pelaku UMKM di Kabupaten Tulungagung di atas, peneliti dapat mengambil kesimpulan bahwa meskipun ada beberapa poin yang telah dipahami, tetapi secara keseluruhan pemahaman pemahaman pelaku UMKM di Kabupaten Tulungagung atas laporan keuangan masih kurang baik. Terbukti bahwa masih ada beberapa responden yang tidak mengetahui siklus akuntansi, tidak mengetahui standar akuntansi untuk UMKM serta rata-rata laporan keuangan yang dipahami hanya laporan laba rugi karena menurutnya yang terpenting dalam usaha adalah dapat mengatahui perkembangan usahanya dan salah satu cara mengukur perkembangan usaha adalah melihat laba usahnya melalui laporan laba rugi. Menurutya laporan laba rugi berguna untuk kepentingan pajak dan untuk pengajuan kredit atau pembiayaan di Bank sebagai tambahan modal. Masih ada beberapa responden belum mengetahu bahkan belum paham bahwa berdasarkan standar akuntansi yang berlaku mengharuskan entitas menyusun laporan laba rugi, laporan perubahan modal, neraca, laporan mutasi kas dan catatan atas laporan keuangan setiap akhir periode.

Peneliti menyimpulkan bahwa pemahaman pelaku UMKM di Tulungagung dipengaruhi oleh latar belakang pendidikan karena berdasarkan hasil penelitian responden dengan latar belakang pendidikan SD dan SMP belum memahami tentang siklus akuntansi, standar akuntansi untuk UMKM bahkan konsep penjurnalan transaksi saja belum memahami terbukti dengan hasil pengisian angket.

Penelitian (Febrianty \& Divianto, 2017) juga menyatakan bahwa pemahaman pelaku usaha terhadap pentingnya laporan keuangan dipengaruhi oleh faktor informasi dan sosialisasi yang diperoleh pelaku usaha, latar belakang pendidikan, lamanya menjalankan usaha dan ukuran usaha yang dijalankan. Faktor terpenting dalam suatu perusahaan salah satunya adalah laporan keuangan karena laporan keuangan menjadi indikator atau petunjuk bagi perusahaan untuk menilai kinerja dari usaha yang dijalankan. Maka dari itu perusahaan harus membuat laporan keuangan termasuk di dalamnya sebuah UMKM. Ketika UMKM memiliki laporan keuangan yang sesuai standar akuntansi yang berlaku makan akan berpengaruh terhadap kemampuannya dalam mengakes lembaga keuangan (Yanto et al., 2017).

Menurut (Risal et al., 2020) pemahaman yang memadai tentang tujuan usaha sangat dibutuhkan jika perusahaan mau maju. Salah satunya yaitu pemahaman tentang pentingnya akuntansi dan laporan keuangan, karena laporan keuangan adalah alat untuk mengetahui kinerja perusahaan dari segi keuangan. Jika pelaku usaha memiliki pemahaman akuntansi yang baik maka mereka cenderung akan memiliki persepsi bahwa dengan menyusun laporan keuangan itu sangat penting untuk mengetahui perkembangan usahanya. Pemahaman akuntansi seorang pelaku UMKM berpengaruh terhadap kualitas laporan keuangannya. Ketika seorang pelaku UMKM memiliki pemahaman akuntansi yang baik dengan didukung pengalaman serta latar belakang pendidikan yang sesuai dengan bidangnya maka laporan keuangannya juga akan baik.

Pernyataan di atas mendukung hasil penelitian oleh (Risal et al., 2020) yang menyatakan bahwa upaya yang bisa dilakukan pelaku UMKM di Indonesia dalam meningkatkan pemahaman akuntansi adalah dengan cara mengikuti program pendidikan atau pelatihan akuntansi baik formal maupun non formal. 
Dengan begitu dapat meningkatkan kapabilitas pelaku UMKM dalam menyusun sebuah laporan keuangan usahanya. Hal tersebut juga didukung hasil penelitian (Kusuma \& Lutfiany, 2019) yang menyatakan bahwa untuk meningkatkan pemaham pelaku UMKM diperlukan semacam program pelatihan atau pendampingan bagi para pelaku UMKM dalam hal mengelola keuangan dengan sistem akuntansi.

\section{Simpulan dan saran}

Berdasarkan pembahasan di atas dapat disimpulkan bahwa persepsi pelaku UMKM di Kabupaten Tulungagung sudah menunjukan persepsi yang baik terbukti dengan hasil penelitian bahwa rata-rata responden sudah mengetahui pentingnya laporan keuangan dalam sebuah usaha diantara untuk mengetahui perkembangan usaha, mendukung kepentingan usaha seperti kepentingan pajak dan kepentingan pengajuan kredit ke Bank sebagai tambahan modal. Persepsi yang baik ini salah satunya dipengaruhi oleh pengalaman atau lamanya menjalankan usaha dan juga latar belakang pendidikan. Namun pemahaman pelaku UMKM di Tulungagung masih perlu ditingkatkan karena masih ada pelaku UMKM di Tulungagung yang tidak mengetahui bagaimana menyusun laporan keuangan sesuai standar yang berlaku meskipun mereka mengetahui pentingnya laporan keuangan. Salah satu penyebabnya adalah rendahnya kompetensi sumber daya manusia yang dipengaruhi oleh latar belakang pendidikan dan pengalaman usaha yang kurang. Khususnya pelaku usaha yang hanya berlatar belakang pendidikan SD. Bahkan ada beberapa pelaku usaha yang tidak mengetahui konsep penjurnalan transaksi padahal hal ini menjadi dasar dalam menyusun laporan keuangan, berdasarkan temuan di lapangan yang terpenting bagi mereka ialah bagaimana menghasilkan profit dalam usaha saja.

Peneliti berharap jika Pemerintah Daerah Kabupaten Tulungagung dan Dinas terkait menjadikan hasil penelitian ini sebagai bahan evaluasi untuk menentukan kebijakan berupa pemberian program pelatihan atau semacam sosialisasi yang bekerja sama dengan Balai Pelatihan Tenaga Kerja atau lembaga lainnya untuk meningkatkan kompetensi akuntansi para pelaku UMKM. Hal ini juga terkait dengan pemenuhan kewajiban pajak, semakin banyak pelaku usaha yang paham tentang pentingnya laporan keuangan maka akan meningkatkan pemenuhan kewajiban pajak UMKM dan hal ini tentunya akan menambah penerimaan pajak. Peneliti juga berharap hasil penelitian ini dapat memberikan bahan pembelajaran bagi pelaku usaha tentang betapa pentingnya laporan keuangan bagi sebuah usaha.

Peneliti menyadari bahwa jurnal ini dari segi teknis maupun kajian teori masih banyak kekurangan. Bagi peneliti selanjutnya peneliti berharap bahwa hasil penelitian ini dapat menjadi dasar untuk melakukan penelitian tentang persepsi dan pemahaman pelaku usaha khususnya UMKM atas pentingnya laporan keuangan, dengan lebih mempertajam penggalian informasi dengan wawancara agar mendapatkan informasi yang lengkap dan valid.

\section{Daftar Rujukan}

Akuntansi, P. S., Tinggi, S., Ekonomi, I., \& Membangun, I. (2020). Persepsi dan Pemahaman Pelaku Usaha UMKM Terhadap Berlakunya Standar Akuntansi Keuangan Entitas Mikro Kecil Menengah di Kota Bandung. 6(3), 72-85.

Ariono, I., \& Sugiyanto, B. (2018). Analisis Faktor-Faktor yang Mempengaruhi Persepsi Atas Informasi Akuntansi Keuangan Serta Keberhasilan dalam Mengelola Perusahan Kecil dan Menengah (Studi Empiris Pada UMKM Industri Makanan di Wonosobo). Journal of Economic, Management, Accounting and Technology, 1(1), 91-104. https://doi.org/10.32500/jematech.v1i1.215

Febrianty, \& Divianto. (2017). Pengaruh Pemahaman Pelaku Ukm Dalam Menyusun Laporan Keuangan Terhadap Implementasi Laporan Keuangan Berdasar Sak Etap Dengan Persepsi Pelaku Ukm Sebagai Moderating Variable. International Journal of Social Science and Business, 1(3), 166-176.

Kurniawati, E., Nugroho, P., \& Arifin, C. (2012). Penerapan Akuntansi Pada Usaha Mikro Kecil Dan Menengah (Umkm). Jurnal Manajemen Dan Keuangan Darmajaya, 10(2), 218956.

Kusuma, I. C., \& Lutfiany, V. (2019). Persepsi Umkm Dalam Memahami Sak Emkm. Jurnal Akunida, 4(2), 1. https://doi.org/10.30997/jakd.v4i2.1550

Mulyani, S. (2014). Faktor-Faktor Yang Mempengaruhi Kualitas Laporan Keuangan Pada Umkm Di Kabupaten Kudus Kata. Jurnal Dinamika Ekonomi \& Bisnis, 11(2), 137-150.

Mutiah, R. A. (2019). Penerapan Penyusunan Laporan Keuangan pada UMKM Berbasis SAK EMKM. International Journal of Social Science and Business, 3(3), 223. https://doi.org/10.23887/ijssb.v3i3.21000

Purwati, A. S., Suparlinah, I., \& Putri, N. K. (2014). The Use of Accounting Information in the Business 
Decision Making Process on Small and Medium Enterprises in Banyumas Region , Indonesia. 17(2), 6376.

Rekarti, E., \& Doktoralina, C. M. (2017). Improving Business Performance: A Proposed Model for SMEs. European Research Studies Journal, 20(3), 613-623. https://doi.org/10.35808/ersj/732

Risal, R., Febriati, F., \& Wulandari, R. (2020). Persepsi Pelaku UMKM Dalam Menyusun Laporan Keuangan. JAD: Jurnal Riset ..., 3(1), 16-27.

Setiyawati, Y., \& Hermawan, S. (2018). Persepsi Pemilik Dan Pengetahuan Akuntansi Pelaku Usaha Mikro Kecil Dan Menengah (Umkm) Atas Penyusunan Laporan Keuangan. Riset Akuntansi Dan Keuangan Indonesia, 3(2), 161-204. https://doi.org/10.23917/reaksi.v3i2.6629

Solikah, M., Astuti, P., \& Paramitha, D. A. (2017). Analisis faktor-faktor Yang Mempengaruhi Persepsi Wirausahawan Terhadap Pentingnya Pembukuan dan Laporan Keuangan. Jurnal Akuntansi \& Ekonomi FE UN PGRI Kediri, Vol. 2(1), Pp 12-21.

Suci, Y. R., Tinggi, S., \& Ekonomi, I. (2017). Perkembangan UMKM (Usaha Mikro Kecil Menengah) di Indonesia. Jurnal Ilmiah Fakultasi Ekonomi, 6(1), 51-58.

Yanto, H., Yulianto, A., Sebayang, L. K. B., \& Mulyaga, F. (2017). Improving the compliance with accounting standards without public accountability (SAK ETAP) by developing organizational culture: A case of Indonesian SMEs. Journal of Applied Business Research, 33(5), 929-940.

https://doi.org/10.19030/jabr.v33i5.10016 